\title{
MENTAL LOAD AND EMOTIONAL STABILITY OF A HIGHER EDUCATION EMPLOYEE WITH A SOCIALLY ACTIVE STATUS
}

\author{
CARGA MENTAL E ESTABILIDADE EMOCIONAL DE UM EMPREGADO DE ENSINO SUPERIOR \\ COM ESTADO SOCIALMENTE ATIVO
}

\section{CARGA MENTAL Y ESTABILIDAD EMOCIONAL DE UN EMPLEADO DE EDUCACIÓN SUPERIOR CON UN ESTADO SOCIALMENTE ACTIVO}

\author{
Irina B. Okhrimenko ${ }^{1}$ \\ Marina A. Stavruk ${ }^{2}$ \\ Irina A. Akhmadullina ${ }^{3}$ \\ Natalia V. Ippolitova ${ }^{4}$ \\ Aleskandr A. Korostelev ${ }^{5}$
}

\begin{abstract}
The article deals with the topic of improving the ways of protecting the interests of employees, namely, the problem of selecting the leader based on the informal characteristics, including the psychological features rather than by the administrative instructions. Based on scientific literature the authors give their understanding of "mental load" and "emotional stability". Using experimental data, the authors prove the hypothesis about the leadership as a result of combination of three factors: firstly, the problem-solving by the group; secondly, the group's composition; and finally, the leader's personal qualities. The research is based on the theoretical and empirical scientific methods' use. 208 employees took part in the survey devoted to the assessment of the Trade Union leader's activity. In conclusion, the authors identified the main components of psychological load and emotional stability of a higher education employee with a socially active status. The researches came to the conclusion that the leader's fundamental basis includes: personal qualities, tolerance, the resistance to the mental stress effects; the ability to create a favorable sociopsychological climate in the team and apply certain motivational and managerial methods; the leadership abilities; and the ability to communicate and solve conflict situations.
\end{abstract}

Keywords: Trade Union, mental load, leader, emotional competence, emotional intelligence, emotional stability.

\footnotetext{
${ }^{1}$ Surgut State University. Okrug, Russia.

${ }^{2}$ Surgut State University, Okrug, Russia,

${ }^{3}$ Kazan Federal University. Kazan, Russia.

${ }^{4}$ Shadrinsk State Pedagogical University. Shadrinsk, Russia.

${ }^{5}$ Togliatti State University. Samara Oblast, Russia.
} 
Resumo: $\mathrm{O}$ artigo trata do tema de melhorar as formas de proteger os interesses dos funcionários, a saber, o problema de selecionar o líder com base nas características informais, incluindo os aspectos psicológicos, e não nas instruções administrativas. Com base na literatura científica, os autores entendem "carga mental" e "estabilidade emocional". Utilizando dados experimentais, os autores comprovam a hipótese sobre a liderança como resultado da combinação de três fatores: primeiro, a solução de problemas pelo grupo; segundo, a composição do grupo; e, finalmente, as qualidades pessoais do líder. A pesquisa é baseada no uso de métodos científicos teóricos e empíricos. 208 funcionários participaram da pesquisa dedicada à avaliação da atividade do líder sindical. Em conclusão, os autores identificaram os principais componentes da carga psicológica e estabilidade emocional de um funcionário do ensino superior com status socialmente ativo. As pesquisas chegaram à conclusão de que a base fundamental do líder inclui: qualidades pessoais, tolerância, resistência aos efeitos do estresse mental; a capacidade de criar um clima sóciopsicológico favorável na equipe e aplicar certos métodos motivacionais e gerenciais; as habilidades de liderança; e a capacidade de se comunicar e resolver situações de conflito.

Palavras-chave: Sindicato, carga mental, líder, competência emocional, inteligência emocional, estabilidade emocional.

Resumen: El artículo aborda el tema de mejorar las formas de proteger los intereses de los empleados, a saber, el problema de seleccionar al líder en función de las características informales, incluidas las características psicológicas en lugar de las instrucciones administrativas. Con base en la literatura científica, los autores dan su comprensión de la "carga mental" y la "estabilidad emocional". Utilizando datos experimentales, los autores prueban la hipótesis sobre el liderazgo como resultado de la combinación de tres factores: en primer lugar, la resolución de problemas por parte del grupo; en segundo lugar, la composición del grupo; y finalmente, las cualidades personales del líder. La investigación se basa en el uso de métodos científicos teóricos y empíricos. 208 empleados participaron en la encuesta dedicada a la evaluación de la actividad del líder sindical. En conclusión, los autores identificaron los componentes principales de la carga psicológica y la estabilidad emocional de un empleado de educación superior con un estado socialmente activo. Las investigaciones llegaron a la conclusión de que la base fundamental del líder incluye: cualidades personales, tolerancia, resistencia a los efectos del estrés mental; la capacidad de crear un clima sociopsicológico favorable en el equipo y aplicar ciertos métodos motivacionales y gerenciales; las habilidades de liderazgo; y la capacidad de comunicarse y resolver situaciones de conflicto.

Palabras clave: Sindicato, carga mental, líder, competencia emocional, inteligencia emocional, estabilidad emocional.

\section{INTRODUCTION}

In modern conditions of social reforming, there are many discussions and disputes around trade unions, their role, and significance. Are Trade Unions needed in a general and do they cope with the role assigned to them in today's realities of sanctions, party oppositions, etc.? Trade Union's work has its specifics. It is Trade Union's work, like no other, the activity of which depends not only on political, socio-economic, legal factors but also on the personal characteristics and qualities of the head of the Trade Union organization, no matter what level it is. He has to act in extreme, difficult situations of responsibility, uncertainty, emotional tension, frustration, and crisis. The talent of the leader in communication with people is based on the whole complex of social and psychological qualities and properties. Therefore, he should be 
as formal as informal leader as a subject for which a particular public organization (group, community, team, and team) recognizes the right to make decisions that are most important and personally significant for a specific community.

Thus, the trust and love of people to their leader plays an important role. Trust in a leader means the recognition of his high merits and powers, the necessity, correctness, and effectiveness of his actions in achieving goals, not because of his official position, but by means of his personal abilities and authority. It is the inner agreement with the Trade Union leader, the willingness to act following his views and plans, which help people, feel satisfied with the leading solutions to the tasks set.

It is based on trust when people follow the leader without any means of coercion. Trust means that people are in inner harmony and unity with the leader. Therefore, Trade Union leaders, in addition to their experience and ability, should also have own mental stability, a high conviction in the rightness of their cause, developed social motivation, the ability to get out of stressful situations, as well as the ability to tolerate large mental loads.

\section{METHODOLOGY}

Research Methods. In order to solve the tasks and verify the starting points, we used a complex of theoretical (analysis, synthesis, generalization, classification, etc.) and empirical (pedagogical experiment, questionnaires, testing, pedagogical observation, the study of psychological, pedagogical and methodological literature, student activity products, method expert assessments, a synthesis of personal and best practices of teachers) research methods, as well as methods of mathematical data processing.

In the current conditions of the education system reforming, when along with the new standards and requirements to the teaching staff, there is a strict professional selection, the Trade Union leader is under the influence of extreme mental stress. The problem of mental load and its regulation for his preservation in scientific, teaching community belongs to the essential areas of theoretical, applied, experimental research in the system 'person to person'.

In our opinion, 'mental load' is an arbitrary process of interaction (interpenetration) between the external factors and conditions (environmental, activity, situational) which are the objective load requirements and the internal conditions (functions, states, properties), i.e. subjective reactions mobilizing or encouraging a personality to a particular activity [17].

At the mental workload's analysis it is necessary to take into account that according to S.L. Rubinstein the primary method of existence of the mental activity is a process originally included in continuous 
interaction with the world, and it is mostly not externally observable and internally hidden form voluntary and involuntary activity of consciousness and overall personality [13].

At study of the given problem it was assumed that leadership occurs as a result of a combination of three factors: the issues to be solved by the group; the group's composition; the leader's personal qualities.

A. Umansky defines leadership as "...the result of interaction among the members of a small group in a specific time period, which is affected by the presence of certain qualities, or their totality in its members, and their manifestation within a particular situation, as well as the mutual influence of existing qualities and a specific situation [1].

We conducted a survey of 208 employees at Surgut State University - a higher education organization of KhMAO-Ugra, Russia.

Among the presented questions, there was one about the evaluation of the Trade Union leader's activity in the organization. (See Fig.1). In addition, it was necessary to write the full name of the Trade Union leader and give an assessment of his activities. According to the results of the survey, 161 employees (82\%) answered the question about the leader's name correctly; and the average rating of the Trade Union leader on a point scale from 1 to 5 was equal to 4.5 points

Fig. 1. Evaluation of the Trade Union leader

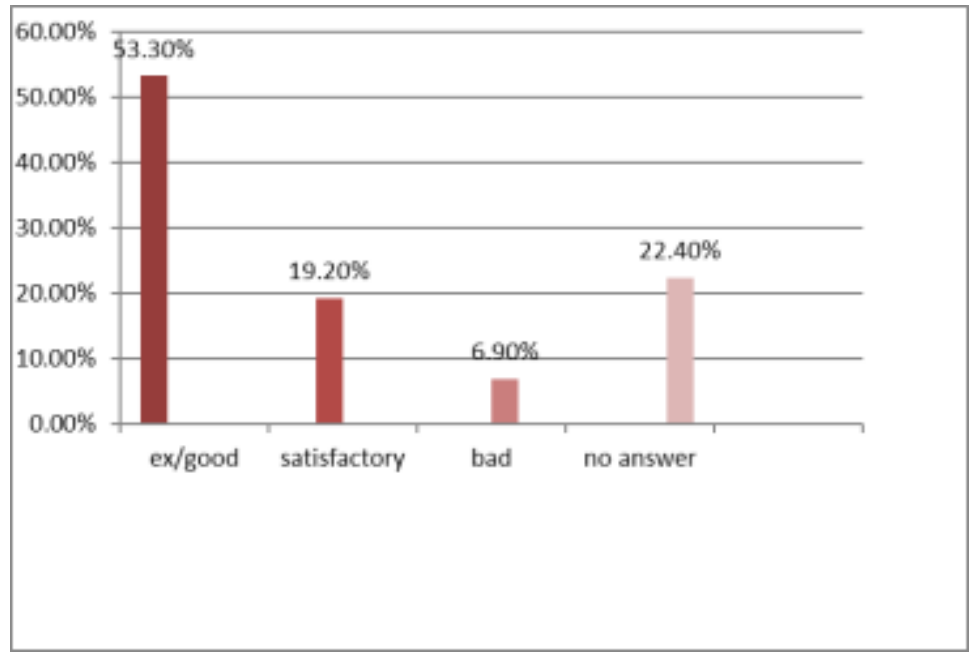

It is worth noting that within the framework of a personal-situational concept there is a well-known theory of "credit of trust (idiosyncrasy credits (eng. "idiosyncrasy" - a character trait, a feature of style) by E. Hollander [21]. The theory is based on the sociometric method of J. Moreno and X. Jennings. It examines the degree of the leader's freedom of action and granting him the right for non-standard behavior with the elements of innovation. It creates the prerequisites for transition of a group functioning to a higher level. 
To have such a right, a Trade Union, especially the leader, must be the personification of the group moral virtues and should possess the competencies necessary for solving the existing and projected problems. At the same time, the level of conformity of his behavior is unstable: sometimes the Trade Union leader has to adapt to intra-group norms, and sometimes to act contrary to them. The credit of trust given to the leader can be either replenished by him or used.

The first case occurs when he meets the role expectations of the group members, and the second one happens when the leader is situationally inactive or incompetent.

Interpersonal assessment is dynamic and can be changed depending on the results of joint activities, during which there is an accumulation of both positive and negative impressions about the Union leader.

Credibility is given not only to the Union leader but also to all members of the group (Trade Union) depending on their contribution to the intra-group purposes' achievement and, accordingly, in case of credibility accumulation by one of the group members alongside with the inappropriate credibility use by the Union leader - may lead to the role reversal. If we follow the theory that a person is a complex motivational organism, and any organised group of people can and should be managed, then the existing conflict between the subjective desire for self-government and the organization-specific process of the roles structuring can be overcome by means of using the situationally appropriate methods of the leadership influence. The choice of these methods will also be influenced by the leader's personal perception of the members of the group.

It is assumed that the Union leader is continuously faced with the need to solve two opposite problems: to be task-oriented and regulate the relationship between people.

This is compounded by the fact that the Trade Union leader communicates as with the representatives of administration at different levels as the members of the team, whose representative he is.

According to R. Blake and J. Muton, the work of the leader can be considered effective when the group members (in our case, the Trade Union Committee) make a feasible contribution to the common problems' solution receiving the desired remuneration of different types. Such leaders demonstrate success both in achieving organizational goals and developing the personal qualities of group members [19].

If we hold the opinion that the leader should structure the group's activities in such a way when at achieving their goals each of its members could make their own contribution to the group goals' implementation, the criterion for effective leadership is the maximum possible endowment of group members with corporate power and their involvement in decision-making process. 
Keeping in mind that the Trade Union leader has been given a "credit of trust" and the members of the team turn to him with a request to solve a large number of social extraordinarily complex problems, then the maximum mental load falls on his share.

It is all kinds of stress: physiological, psychological, emotional, informational, professional.

Professional stress is a phenomenon that manifests itself in physical and mental reactions to stressful situations in the professional activity of the leader. [20]

Among the most stressful professional requirements for the «person to person» professions within the leader's mental load V. A. Ababkov and M. Perre allocate such factors as:

- $\quad$ long-term and intensive communication;

- $\quad$ insufficient training;

- emotional relationships with clients and subordinates;

- $\quad$ professional responsibility;

- $\quad$ inability to help or act effectively;

- $\quad$ isolation from peer support;

- $\quad$ insufficient moral and material incentives. [1]

According to L. Popov, I. Sokolov the main stressors of management activities in the framework of the leader's mental load include such factors as:

- $\quad$ information loads;

- information uncertainty;

- $\quad$ interpersonal conflicts;

- intrapersonal conflicts (executing two or more functional roles at the same time);

- $\quad$ divergence of requirements that are put forward by different roles;

- $\quad$ multi-focus management activities. [18]

Thus, in modern conditions, the most important requirement for a Trade Union leader is to be emotionally competent, stable, and socially tolerant.

The decision to develop the emotional competence is an important task, especially when you are constantly faced with the certain problems and conflict situations in the group interaction of administration and employees.

The leader requires a high level of emotional competence including the ability to withstand the extreme mental stress and creatively fulfill the collective requests discarding usual patterns. 
In a broad sense, we understand the emotional competence as a special personal education that determines the effectiveness of interpersonal interaction. In a narrower sense, the emotional competence is an integrative personal property that reflects a person's predisposition to maintain emotional regulation and self-regulation and includes the basic components - emotional intelligence and emotional stability.

The term "emotional intelligence" (EQ) was introduced in 1990 by the American psychologists Peter Saloway and John Mayer, even before the concept of "emotional competence". By emotional intelligence, the authors mean "the ability to track one's own and others' feelings and emotions, distinguish them, and use this information to guide thinking and action" [10]. There are two points of view on the order of EQ and emotional competence: one identifies these concepts, the other one differentiates them.

Thus, the content of the concept of emotional competence is ambiguous for different authors due to its complexity.

Undoubtedly, the emotional competence is closely related to the concept of emotional intelligence, so many researchers identify these concepts. Some researchers consider the emotional competence as a part of emotional intelligence (D. Goleman, I. N. Andreeva, E. L. Yakovlev) and as an independent phenomenon (E. V. libina, K. Saarni, G. V. Yusupova, etc.) $[7,8]$.

A well-known journalist, a psychologist, and the author Daniel Goleman believes that emotional competence is a part of the emotional intelligence and consists of two components: personal competence (includes three blocks: self - understanding, self-regulation, and motivation) and social competence (includes two blocks: empathy and social skills) $[16,17]$.

Thus, we can note that the idea of the emotional competence was the result of developing tthe ideas about the emotional intelligence, which in turn fits into the system of knowledge about the emotional sphere of a person. In our opinion, we should separate these two concepts.

M.A. Manoilova notes the need to form the emotional intelligence of teachers and students of pedagogical educational institutions. According to the author, the emotional intelligence is a system-forming factor of the pedagogical activity's productivity, mediating both the acquisition of professional knowledge and skills and the teachers' personal development. The emotional intelligence (EI) of a teacher is determined by the formation of such qualities as empathy, communicative tolerance, assertiveness (self-confidence), self-esteem, and the level of claims [5].

For El's formation M. A. Manoilova offers a program that integrates problem-oriented and active socio-psychological methods in the process of teaching students of Pedagogical Universities.

I.N. Andreeva studies the relationship of these definitions. She believes that the emotional competence is related to emotional intelligence and based on it. Thus, a certain level of El is necessary for 
training specific competencies related to emotions. For example, the ability to understand other people's emotions makes it possible to develop competencies such as the ability to influence and inspire others. Similarly, the ability to manage your emotions makes it easier to develop the initiative and the ability to work in a stressful situation [2].

K. Saarni believes that the main difference between the emotional intelligence (EI) and the emotional competence (EC) is that EC includes the skills necessary for successful adaptation and coping within the immediate social environment. If the level of $\mathrm{El}$ is largely determined by hereditary factors, the EI is formed by the influence of family, peers, school, media, social scenarios, and popular ideas about how emotions "operate" [2].

The developed emotional competence is the most important personal quality of every effective teacher, psychologist, and structural manager. Researchers working in this direction in business and management, i.e. in the "person-to-person" system believe that if a person has a high IQ, but his EQ is very low, it is unlikely that he will be able to be a successful manager. After all, the work of a manager consists of $90 \%$ of communication: communicative, perceptual, interactive ones, the success of which directly depends on the coefficient of emotional intelligence. It is established that the more effective and successful Manager, the more emotional intelligence is laid in the foundation of his success [11].

\section{EMOTIONAL STABILITY}

We consider the category of emotional stability as a special class of mental manifestations, reflected in the form of direct, subjective experience of the personal meaning of these phenomena, objects, and situations so that to meet own needs [4 p.459-460,17].

All researchers recognize that emotions affect almost all aspects of human existence in different directions, and the emotional stability is a factor that largely determines the effectiveness of performance.

In science, the concept of emotional stability is considered from many possible options, i.e. from different conceptual positions including as the functional stability of a person to emotional conditions, as the stability of a certain emotional state (emotional stability), and as personal feature.

Despite this contradiction, the attention of scientists and practitioners is still attracted to the solution of this problem in the aspects of emotional competence [16]. The researchers note that the knowledge of individual characteristics of emotional stability contributes to the emergence of the rational conscious selfregulation, that is, the internal mental activity of the subject of activity, which in its structure and content contributes to the goals' achievement [16 ]. 
In our research, we adhere to the concept introduced by G. Eisenk and reformulated by L.P. Badanina, that emotional stability is an integrative personal property reflecting a person's predisposition to maintain emotional balance including the low anxiety, neuroticism, and self-confidence. [4, p. 229].

However, many researchers have considered only the elements of the problem, without giving a complete picture of the essence of this phenomenon.

Emotional instability is an integrative personal property that reflects a person's predisposition to the emotional balance disorders and includes motivation to avoid failure, increased anxiety, fears, and neuroticism [18].

Confidence in one's emotional competence is based on self-assessment processes: the idea that a person can accept and manage his emotions [14]. Therefore, the development of adequate self-esteem is an integral part of forming the emotional competence of any person and the leader, in particular.

Emotional stability means preserving the productive functioning of the human psyche in a short-term or long-term stressful situation.

Mental stability is a prerequisite for overcoming difficulties, the active and error-free performance of tasks in difficult situations. specially if we are talking about the Trade Union social work, where it is often necessary to act quickly and productively in the context of higher school reform. Mental stability to concentrate and distribute attention, navigate, use knowledge, skills, and withstand large external and internal loads [17].

Several habits will help you improve and develop this quality. Many of the characteristics of mentally stable people represent special strategies that can be applied in life today.

Emotional intelligence is the cornerstone of mental stability. You can't be mentally stable without being able to fully recognize and live through strong negative emotions and turn them to your advantage. All the events that test the strength of your psyche, ultimately affect the emotional intelligence (EQ). Unlike IQ, which remains more or less unchanged, EQ is a flexible skill that, with the right approach and proper effort, can be developed and pumped. It is not surprising that $90 \%$ of the most successful people have a high EQ, and that people with a high EQ earn much more on average than their colleagues with a lower score.

Unfortunately, developed EQ is not common. 'Talent Smart' has studied more than a million people and found that only $36 \%$ of respondents can accurately determine their emotions at the moment they occur. [16].

Emotional stability - non-subjection of emotional states of processes to destructive influence of internal and external processes. Emotional stability is an integral property of the psyche, which is expressed in the ability to overcome the state of excessive emotional excitement at performing complex activities. 
Emotional stability reduces the negative impact of strong emotional influences, prevents extreme stress, and contributes to the manifestation of readiness to act in a stressful situation. [17].

Tolerant leaders have a social perception, can show pedagogical tact, mobility, and constantly adapt. They know that the fear of change can paralyze and become a serious threat to their happiness and success. They are always open to new ideas and have got a plan ready to help them implement their ideas. Thus, a leader is a person who is not afraid to take responsibility, who knows what he wants and how to achieve it. Leaders are at the head of large groups of people, lead large companies, create parties, and determine the directions of development for the rest of the people who agree to obey and trust the authoritative opinion.

To win a leading position a person must have a set of personal qualities and a strong character to maintain dominance in any situation. People are ready to recognize the leadership of a person who can see prospects, stimulate the team and maintain the faith in success, to be sensitive to changes, and respond to them.

They also need courage, ambition, organization, and, of course, stress resistance. The development of stress tolerance is one of the basic components of the leader's emotional competence.

Emotional competence is a set of knowledge, skills, and abilities that make it possible to apply adequate solutions and act based on the results of the intellectual processing of external and internal emotional information.

\section{CONCLUSION}

The ability of a Trade Union leader to create a favorable socio-psychological climate in the team, interest employees in their work, apply certain motivational and managerial methods, show their leadership abilities, communicate and solve conflict situations is a fundamental basis of a leader. This depends not only on the chosen leadership style and affects the effectiveness of the organization, but first of all, on the personal qualities of the leader and his competence, his ability to resist the influence of mental stress, and to have good physical and mental health.

Today, Trade Union is the only organization that should be a democratic tool for protecting the employees' interests.

Unlike the political parties, which show themselves as defenders of social justice, especially during election campaigns, Trade Unions live by the concerns of their colleagues from day to day, from year to year, and help people. This factor is the key to their longevity. Playing the role of "the eternal opposition" is a heavy burden, especially for those people who do not have internal personal attitudes. Psychological 
difficulties arise, perhaps, for all professional leaders because they do not have the necessary support and protection from the people whose interests they protect which have elected them and delegated the powers.

\section{REFERENCES}

1. Ababkov V. A. Adaptation to stress. Fundamentals of theory, diagnosis, therapy / V. A. Ababkov, M. perre. - SPb. : Speech, 2004. - 166 p.

2. Andreeva, I. N. Development of emotional competence of teachers Text. / I. N. Andreeva // Psychology of education today: Theory and practice: proceedings of the international conference. practical Conf. - Minsk, 2003. - Pp. 166-168.

3. Anisimov, O. S. Fundamentals of General and managerial acmeology Text: textbook. manual / O. S. Anisimov, A. A. Derkach. - M.; Novgorod, 1995. -272 p.

4. Vagin, I. How to become a billionaire. Practical coaching Text. / I. Vagin, P. Ripinskaya. M.: ACT, Astrel, 2004. - 304 p.

5. Gozman, GI. Ya. Psychology of emotional relations Text. / L. Ya. Gozman. M.: MSU Publishing house, 1987. - $174 \mathrm{p}$.

6. Goleman, D. Emotional leadership. The art of managing people based on emotional intelligence Text. / D. Goleman, R. Boyatsis, E. McKee. M.: Alpina Business books, 2005. - Pp. 266-269.

7. Goleman, D. Emotional intelligence text. / D. Goleman. M.: ACT, 2008. - 480 p.

8. Drucker, P. F. Practice of management Text. / P. F. Drucker; TRANS. with English. M.: Williams, 2000. - $398 p$.

9. Drucker, P. F. XXI XXI century = Management of challenges in the 21st century text. / P. F. Drucker. - M.:" Williams", 2007. - 272 p.

10. Kabachenko, T. S. Methods of psychological influence Text: textbook. manual / T. S. Kabachenko. - M.: PED. about Russia, 2000. 544 p.

11. raichenko A.V. General management: Textbook for universities. Moscow: Infra-M, 2009. 384 p.

12. reynolde, M. Coaching: emotional competence: Direct your emotions (EC>) to success in work text. / M. reynolde. - Moscow: TSPKUB, 2003.- 112 p.

13. Roberts, R. D. Emotional intelligence: problems of theory, measurement and application in practice Text. / R. D. Roberts, J. Matthews, M. Seidner, D. V. Lucin // Psychology: Journal Of The Higher School Of Economics. 2004. - Vol. 1. - No. 4. - P. 3-24.

14. Rubinstein S. L. Fundamentals of General psychology.- M.: Uchpedgiz, 1946. - 704 p. 89.

15. Harris, J. Coaching: personal growth and success text. / J. Harris. SPb.: Speech, 2003. - 112 p.

16. Chumakova, S. coaching of emotional competence (equalizer). (Equalizer-a powerful resource for a successful Manager) electronic resource. / S. Chumakova access mode // http://coacha.ru/help/publications/20030619.html 
17. Yakovlev B. P., Litovchenko O. G. Theoretical aspects of research of mental load in the conditions of educational activity.- Alma mater (Bulletin of the higher school).,- 2005. № 6. P. 3-6.

18. Stres zhitya: Zbirnik / ukladachi: L. M. Popova, I. V. Sokolov. - Saint Petersburg: Leila LLP, 1994. $384 \mathrm{p}$.

19. Charan, R. leadership pipeline. How to build a company based on leadership / R. Charan, S. Drotter, J. Noel. San Francisco: Jossey-Bass, 2001.

21. Cohen Allan R. influence without authority / Allan R. Coehn, David L. Bradford. - New Jersey: John Wiley \& sons, Inc, 2005.

DIAS, A. F.; MENEZES, C. A. A. Que inovação pedagógica a pedagogia queer propõe ao currículo escolar?. Revista Tempos e Espaços em Educação, v. 10, n. 23, p. 37-48, 2017.

22. Orekhova, Y.Y., Grebenkina, L.K., Suvorova, N.A., Stavruk, M.A., Pedagogical conditions of formation of professional competence of students of a technical university // Periodico Tche Quimica, 2020.

23. Yakovlev B.P., Stavruk M.A., Dumova T.B. Psychodynamic influence on first and second year students' adaptation to educational activity / The European Proceedings Of Social \& Behavioural Sciences , 2018.

24. KOVACS, H.; TINOCA, L. Unfreeze the pedagogies: introduction of a new innovative measure in Portugal. Revista Tempos e Espaços em Educação, v. 10, n. 23, p. 73-86, 2017.

\section{$\underline{\text { ABOUT THE AUTHORS }}$}

Irina B. Okhrimenko

PhD in Pedagogics. Surgut State University, Okrug, Russia.

E-mail: nkuni19@yandex.ru

ORCID: https://orcid.org/0000-0002-0636-0563

\section{Marina A. Stavruk}

PhD in Pedagogics. Surgut State University, Okrug, Russia.

E-mail: nkuni20@yandex.ru

ORCID: https://orcid.org/0000-0002-5733-9687

Irina A. Akhmadullina

PhD in Pedagogics. Kazan Federal University, Kazan, Russia.

E-mail: akhmadullina19@mail.ru

ORCID: https://orcid.org/0000-0002-6280-6240

\section{Natalia V. Ippolitova}

Shadrinsk State Pedagogical University. Shadrinsk, Russia.

E-mail: uni.state-2019@yandex.ru

ORCID: https://orcid.org/0000-0002-1453-4711 
Aleskandr A. Korostelev

Togliatti State University. Samara Oblast, Russia.

E-mail: korostelev19@mail.ru

ORCID: https://orcid.org/0000-0002-7602-7758

Received on: 07-12-2020

Approved in: 10-10-2020

Published in: 11-05-2020 